\title{
Isolation and characterization of the human AKT1 gene, identification of 13 single nucleotide polymorphisms (SNPs), and their lack of association with Type II diabetes
}

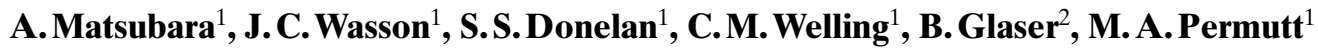 \\ ${ }^{1}$ Division of Metabolism, Endocrinology and Diabetes, Washington University School of Medicine, St. Louis, Missouri, USA \\ ${ }^{2}$ Department of Endocrinology, Hadassah Medical Center, Jerusalem, Israel
}

\section{Abstract}

Aims/hypothesis. AKT1, a serine/threonine protein kinase, is an important downstream target of the insulin-signalling pathway, with both anti-apoptotic and peripheral metabolic effects. Because impaired insulin signalling is a major hallmark of Type II (non-insulin-dependent) diabetes mellitus, we considered whether the $A K T 1$ gene could be a candidate gene involved in susceptibility of this condition. To test this possibility, we isolated and characterized the human $A K T 1$ gene. We also looked for single nucleotide polymorphisms in the gene and examined their association with Type II diabetes mellitus in the Ashkenazi Jewish population.

Methods. Human BAC/P1 genomic libraries were screened to isolate the AKT1 gene. To obtain structural information and the sequences of the exon-intron boundaries, BAC/P1 clones were directly sequenced. Identification of single nucleotide polymorphisms was done by polymerase chain reaction of each exon, followed by denaturing high performance liquid chromatography. Six single nucleotide polymorphisms were genotyped in Ashkenazi Jewish patients with Type II diabetes mellitus and in control subjects.

Results. The human AKT1 gene was at least $24.6 \mathrm{~kb}$ in length and comprised 14 exons. Altogether 13 putative intragenic single nucleotide polymorphisms, with minor-allele frequencies ranging from 0.011 to 0.354 , were identified. The allelic and the genotypic frequencies of 6 single nucleotide polymorphisms were the same in diabetic patients and in control subjects.

Conclusion/interpretation. The results of our studies show that the $A K T 1$ gene is not a major contributor to susceptibility to Type II diabetes mellitus in Ashkenazi Jews. [Diabetologia (2001) 44: 910-913]

Keywords $A K T 1$, single nucleotide polymorphism, Type II diabetes mellitus, linkage disequilibrium, Ashkenazi Jews.
The AKT (murine thymoma viral ( $v$-akt) oncogene homologue), also termed protein kinase $\mathrm{B}$ (PKB) or $\mathrm{RAC}$ protein kinase, is a serine and threonine protein kinase homologous to protein kinases $\mathrm{A}$ and $\mathrm{C}$ [1][2].

Received: 18 January 2001 and in revised form: 2 April 2001

Corresponding author: M. A.Permutt, Division of Metabolism, Endocrinology and Diabetes, Washington University School of Medicine, 660 South Euclid, Box 8127, St. Louis, MO 63110, USA. E-mail: apermutt@im.wustl.edu

Abbreviations: RT, Reverse transcriptase; PCR, polymerase chain reaction; SNP, single nucleotide polymorphism; DHPLC, denaturing high-performance liquid chromatography; LD, linkage disequilibrium; EST, expressed sequence tag.
Three mammalian isoforms (AKT1-3) have been cloned. For maximal enzymatic activation of AKT1, Thr-308 and Ser-473 are required to be phosphorylated by 3-phosphoinositide-dependent protein kinase-1 (PDK1) and 3-phosphoinositide-dependent protein kinase-2 (PDK2) respectively, while PDK2 has yet to be identified. AKTs are important for many cellular processes such as growth and differentiation and have anti-apoptotic effects through several target molecules. AKT also mediates a variety of peripheral metabolic actions of insulin.

Recent experiments in transgenic mice, including tissue-specific disruptions of the islet beta cell insulin receptor (IR) and the insulin receptor substrates 
IRS1 and IRS2, have shown that insulin-signalling pathways are important for beta cell growth and function $[3,4]$. The AKT has been shown to be an important downstream target of the insulin-signalling pathway. More recently, pancreatic islet beta cell-specific $A K T 1$ transgenic mice were observed to have a much higher beta cell mass and insulin content, suggesting that AKT1 could be a key regulator in normal beta cell growth [5]. Our reverse transcriptase (RT)PCR analysis of insulinoma cell (MIN6) mRNA showed that AKT1 was the predominant isoform in this beta cell line (H. Inoue, unpublished observation).

In view of the fact that genetic defects in the $A K T 1$ gene could be associated with either impaired insulin action, beta cell growth or both, we considered whether this gene could predispose to Type II (noninsulin-dependent) diabetes. A previous study has examined genetic variants in $A K T 1$ in 70 Danish Caucasian patients with Type II diabetes [6]. Because the genomic structure of $A K T 1$ was not known, the investigators carried out RT-PCR of $A K T 1$ mRNA isolated from skeletal muscle biopsies. The resulting products were analysed by single strand conformational polymorphism and heteroduplex analysis revealing a single variant $\left(\mathrm{Tyr}^{\mathrm{tac}} 417 \mathrm{Tyr}^{\mathrm{tat}}\right)$ with allelic frequency of $2 \%$. In this study, we isolated the human $A K T 1$ gene from large insert bacterial clones of human genomic DNA, characterized its structure, and tried to identify potential mutations in the gene in patients with Type II diabetes. Altogether 13 intragenic single nucleotide polymorphisms (SNPs) were identified and the allelic frequencies of 6 SNPs belonging to Ashkenazi Jewish patients with Type II diabetes and control subjects were compared.

\section{Subjects and methods}

General molecular biological procedures. Standard molecular biology techniques were used [7]. Taq-Gold DNA polymerase was purchased from Perkin-Elmer/Cetus (Foster City, Calif., USA), and PCR amplification was done according to the supplier's protocols. Restriction enzymes and other modification enzymes were purchased from NEB (Beverly, Mass., USA) and Promega (Madison, Wis., USA). Oligonucleotides were synthesized in the Protein Chemistry Laboratory, Washington University School of Medicine. DNASTAR ${ }^{\mathrm{TM}}$ software (Madison, Wis., USA) was used for analysis of DNA sequences.

Subjects and genomic DNA. All subjects were participants in a genome scan of Type II diabetes in Ashkenazi Jews as described previously [8]. The study was approved by the institutional review board of Washington University School of Medicine. Type II diabetes was defined according to the 1980-1985 WHO criteria. Genomic DNA was extracted from whole blood using the Puregene Genomic DNA extraction kit (Gentra System, Minneapolis, Minn., USA). For the SNP screening by denaturing high-performance liquid chromatography (DHPLC), 30 unrelated probands who had the highest evidence of linkage to chromosome $14 \mathrm{q}$ based on the identity-by-descent (IBD) probability of 5 markers between D14S606 and D14S267 were selected from a large set of affected sib pairs [8]. An association study using individual SNPs was carried out by comparing allelic and genotypic frequencies in Type II diabetes patients $(n=69)$ and control subjects $(n=65)$. The average fasting plasma glucose concentrations and $\mathrm{HbA}_{1 \mathrm{c}}$ of diabetic patients were $178.5 \pm 7.8 \mathrm{mg} / \mathrm{dl}$ and $\mathrm{HbA}_{1 \mathrm{c}} 9.0 \pm 0.2 \%$, respectively. Mean BMI of Type II diabetic patients was higher than that of control subjects $\left(29.3 \pm 0.7\right.$ vs. $25.5 \pm 0.4 \mathrm{~kg} / \mathrm{m}^{2}$, mean \pmSEM, $p<0.001)$. The ages of the two groups differ $(p<0.001)$ because patients $(55.0 \pm 1.2$ years $)$ were initially recruited only if Type II diabetes was present in at least one family member who was under 55 years of age, and control subjects were selected for normal glucose tolerance by $75 \mathrm{~g}$ OGTT in an older population (75.4 \pm 1.1 years) [8]

Isolation of human genomic clones and DNA sequencing. To isolate human $A K T 1$ genomic clones, PCR primers were selected from the published sequence of the human AKT1 cDNA (GenBank Accession NM_005163). One set of primers was chosen from the 3'-untranslated region of this cDNA sequence, AKT1F1: 5'-CACCAGATGCAACCTCACTA-3', AKT1R1: 5'-TAAACCTTGCTCCTCTGTCC-3' (185 bp, primer annealing sites at nt. positions 2076-2095 and 2241-2260, respectively). Another set was chosen from the 5'end of the cDNA sequence, AKT1F2: 5'-GCCTGGGTCAAAGAAGTCAA-3', AKT1R2: 5'-TAGCCACGTCGCTCATGGTG-3' (approximately $600 \mathrm{bp}$, primer annealing sites at nt. positions 58-77 and 195-214, respectively). The AKT1F1 and AKT1R1 were used for radiation hybrid mapping using the GeneBridge 4 panel (Research Genetics, Huntsville, Ala., USA). The human genomic BAC library (CITB Human BAC Library, Research Genetics) and P1 library (HDK) were screened by PCR, using primers AKT1F1/AKT1R1 and AKT1F2/AKT1R2, respectively [9]. To obtain structural information and intronic sequences of the $A K T 1$ gene, the BAC and P1 DNA clones were purified and sequenced with an ABI Automated Sequencer Model 377 using the ABI Prism BigDye Terminator Cycle Sequencing kit (PE Applied Biosystems, Foster City, Calif., USA). By comparing the sequences obtained and the reported cDNA sequence, intron-exon boundaries were determined and the $\mathrm{BAC} / \mathrm{P} 1$ sequencing was continued until the entire coding sequence and exon-intron boundaries were obtained.

SNP identification and genotyping. For SNP screening, heteroduplexes of PCR products from each patient with those from a control homozygous individual (wild-type DNA) were analysed by the DHPLC using a Transgenomic WAVE HPLC (Transgenomic, Omaha, Neb., USA) and DNASep column (Transgenomic) following the manufacturer's instructions. DNA fragments with aberrant elution profiles were re-amplified and sequenced directly. For genotyping individual SNPs, PCR products were digested with restriction enzymes shown in Table 1 and analysed by agarose-gel electrophoresis.

Statistical analysis. Differences between groups in allelic and genotypic frequencies were assessed by Fisher's exact test and chi-square tests, with Yates' correction as needed (InStat ${ }^{\mathrm{TM}}$, GraphPad Software, San Diego, Calif., USA). Linkage disequilibrium (allelic associations) between pairs of SNPs was assessed by the ASSOCIATE program (http://linkage.rockefeller.edu/ott/linkutil.htm). A $p$ value of less than 0.05 was considered statistically significant. 
Table 1. Single nucleotide polymorphisms in the $A K T 1$ gene

\begin{tabular}{|c|c|c|c|c|c|c|}
\hline Polymorphism & Designation $^{\mathrm{a}}$ & Location & Type & Flanking Sequence Information ${ }^{\mathrm{b}}$ & $\begin{array}{l}\text { Restriction } \\
\text { Enzyme }\end{array}$ & $\begin{array}{l}\text { Frequency of } \\
\text { Minor Allele }(n)\end{array}$ \\
\hline SNP1 & c. $-350 \mathrm{G} \rightarrow \mathrm{T}$ & $5^{\prime}-\mathrm{UT}^{\mathrm{c}}$ & Non-coding & cccagg aggtttttg $(\mathrm{G} / \mathrm{T})$ gcttgcgctggaggg & Xcm I & T: $0.233(258)^{\mathrm{f}}$ \\
\hline SNP2 & $\mathrm{IVS} 2+42 \mathrm{C} \rightarrow \mathrm{T}$ & Intron 2 & - & ctggggagggagaga $(\mathrm{C} / \mathrm{T})$ aggggtagtagcccc & - & $\mathrm{ND}^{\mathrm{d}}$ \\
\hline SNP4 & $\mathrm{IVS} 3+18 \mathrm{C} \rightarrow \mathrm{T}$ & Intron 3 & - & aagtatcccttggc $(\mathrm{C} / \mathrm{T})$ tctcgggattcagat & Hae III & T: 0.155 (264) \\
\hline SNP5 & IVS3-113 C $\rightarrow \mathrm{T}$ & Intron 3 & - & agagatggggettcc $(\mathrm{C} / \mathrm{T})$ aggacctggtgggtg & PflM I & T: 0.270 (264) \\
\hline SNP6 & $\mathrm{IVS} 4+30 \mathrm{~A} \rightarrow \mathrm{G}$ & Intron 4 & - & gcggccaggccaggc $(\mathrm{A} / \mathrm{G})$ cttgggcagcccag & Hha I & $\mathrm{ND}^{\mathrm{d}}$ \\
\hline SNP9 & c.726 A $\rightarrow \mathrm{G}$ & Exon 9 & Synonymous ${ }^{\mathrm{e}}$ & ccacctgtcceggga $(\mathrm{A} / \mathrm{G})$ cgtgtgttctccgag & Afl III & A: $0.206(262)$ \\
\hline SNP10 & $\mathrm{IVS} 11+23 \mathrm{~A} \rightarrow \mathrm{G}$ & Intron 11 & - & ccgcccatcccagct $(\mathrm{A} / \mathrm{G})$ caggctacacctcca & Pvu II & G: 0.354 (48) \\
\hline SNP11 & IVS11 + $69 \mathrm{G} \rightarrow \mathrm{C}$ & Intron 11 & - & gctgcacctgccct (G/C) cgccaggcggtcctg & Hha I & C: $0.250(48)$ \\
\hline SNP12 & IVS11-89 C $\rightarrow \mathrm{T}$ & Intron 11 & - & gaacgtcctgtctgg $(\mathrm{C} / \mathrm{T})$ gggccctacatcaca & Aci I & T: $0.012(254)$ \\
\hline SNP13 & $\mathrm{IVS} 12+66 \mathrm{C} \rightarrow \mathrm{T}$ & Intron 12 & - & acactcacgcatgca $(\mathrm{C} / \mathrm{T})$ gtggcacgctcgcca & Nsi I & T: 0.011 (264) \\
\hline
\end{tabular}

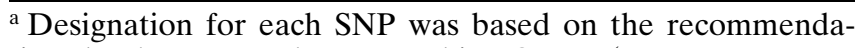
tions by the Nomenclature Working Group (Human Mutation 1998;11(1):1-3). The c. preceded the nucleotide number of the reference cDNA sequence (GenBank Accession NM_005163), denoting the A of the ATG of the initiator Met codon as +1 . Intronic polymorphisms were designated by the intron (IVS) number, positive numbers starting from the $G$ of the donor site invariant GT, negative numbers starting from the $\mathrm{G}$ of the acceptor site invariant AG. ${ }^{\mathrm{b}}$ Alleles (upper case) are shown, with flanking sequences (lower case). '5'-UT; 5' untranslated sequence. ${ }^{\mathrm{d}} \mathrm{ND}$; not determined. ${ }^{\mathrm{e}} \mathrm{Glu}^{\mathrm{gaa}} 242 \mathrm{Glu}^{\mathrm{gag}}$. ${ }^{\mathrm{f}}$ Frequency of minor allele $\mathrm{T}$ was 0.229 with screening 421 (274 of Type II diabetes, 147 of control) subjects.

\section{Results}

Isolation and characterization of the human AKT1 gene. The BAC clone (CITB150E7) did not contain the 5'-end of the AKT1 gene. The P1 (HDK45E6) clone did not contain the 3'-end. These clones overlapped with each other and covered the entire coding region of the $A K T 1$ gene. The human $A K T 1$ gene was estimated to be at least $24.6 \mathrm{~kb}$ in length and to be composed of 14 exons, with the first ATG and open reading frame observed in exon 2 (GenBank Accession numbers AF283818-AF283830). All exon/intron junctions of $A K T 1$ contain consensus donor/splice junctions. A sequence comparison of our genomic, reference cDNA and the EST sequences showed an exact sequence match up to $492 \mathrm{bp}$ of 5'untranslated sequence of the $A K T 1$ gene but we did not map precise transcription initiation site(s). Thus, the possibility of an additional exon(s) encoding an additional 5'-untranslated region cannot be fully excluded.

The human $A K T 1$ gene was previously mapped to chromosome $14 \mathrm{q}$ in a human-rodent somatic hybrid panel and to $14 \mathrm{q} 32.32$ by in situ hybridization (UniGene \# Hs.71816). Two-point RHMAP analysis of our $\mathrm{RH}$ results at the Sanger RH Mapping Server (http://www.sanger.ac.uk/Software/RHserver/) indicated that the gene was linked to a polymorphic marker (D14S272), with a lod score of 12.651. The D14S272 has been previously mapped at $124.2 \mathrm{cM}$ on chromosome 14 (1996 Genethon map), and at 14q32.1-14q32.3 by Chr 14 Cytogenetic Map (HUGO Chromosome Committee 14). Further, the multipoint RHMAPPER option placed the gene within RH framework interval no. 37 on the 1998 Gene
Map (http:www.ncbi.nlm.nih.gov/genemap98/), the most telomeric region on chromosome 14 between D14S272 (275.98 cR) -qTEL (290.71 cR).

SNP identification. All 14 exons with flanking intronexon junctions of the $A K T 1$ gene were examined. Altogether 13 putative intragenic SNPs were detected.

Of these, 1 encoded a silent codon change in exon 9 (SNP9; Glu ${ }^{\text {gaa }} 242 \mathrm{Glu}^{\text {gag }}$ ) and 11 were intronic variants that did not seem to have any functional consequences, as they did not affect splice junctions. The remaining SNP (SNP1; c.-350 G $\rightarrow$ T) was located at the very 5 '-end of the gene. Using the dbEST database, we found two EST sequences (GenBank Accession H41956 and AI597912) that matched this 5'variant. Thus we concluded that SNP1 is located in the 5'-untranslated region of exon 1 . Of note, the single $A K T 1$ SNP previously reported in $2 \%$ of Danish Caucasian patients with Type II diabetes (Tyr ${ }^{\text {tac }} 417-$ $\mathrm{Tyr}^{\mathrm{tat}}$ ) was not found in our population [6]. In this study, we did not look for the promoter and other regulatory sequence(s) for polymorphisms for the reasons mentioned above.

Altogether nine of these variants either created or abolished restriction endonuclease sites in genomic DNA. The frequencies of these variants were subsequently determined in at least 24 control subjects by PCR-RFLP analysis (Table 1). Based on the results of these frequencies and locations within the gene, six SNPs (SNP1, 4, 5, 9, 12 and 13) were used for subsequent analysis. 
Table 2. Genotypic and allelic frequencies in Type II diabetic patients and control subjects

\begin{tabular}{|c|c|c|c|c|c|c|c|c|}
\hline \multicolumn{2}{|c|}{ Polymorphism } & \multicolumn{3}{|c|}{$\begin{array}{l}\text { Genotype } \\
\text { Number (frequencies) }\end{array}$} & \multirow{2}{*}{$\begin{array}{l}\begin{array}{l}\text { Chi-square } \\
\left(\chi^{2} / p \text {-value }\right)\end{array} \\
2.81 / 0.25^{\mathrm{a}}\end{array}$} & \multicolumn{2}{|c|}{$\begin{array}{l}\text { Allele } \\
\text { Number (frequencies) }\end{array}$} & \multirow{2}{*}{$\begin{array}{l}\begin{array}{l}\text { Fisher's Exact } \\
(p \text {-value })\end{array} \\
0.10\end{array}$} \\
\hline $\mathrm{SNP}^{\mathrm{c}}$ & $\begin{array}{l}\text { Type II diabetic } \\
\text { Control subjects }\end{array}$ & $\begin{array}{l}\mathrm{G} / \mathrm{G} \\
169(0.62) \\
79(0.54)\end{array}$ & $\begin{array}{l}\mathrm{G} / \mathrm{T} \\
94(0.34) \\
59(0.40)\end{array}$ & $\begin{array}{l}\mathrm{T} / \mathrm{T} \\
11(0.04) \\
9(0.06)\end{array}$ & & $\begin{array}{l}\mathrm{G} \\
432(0.79) \\
217(0.74)\end{array}$ & $\begin{array}{l}\mathrm{T} \\
116(0.21) \\
77(0.26)\end{array}$ & \\
\hline SNP4 & $\begin{array}{l}\text { Type II diabetic } \\
\text { Control subjects }\end{array}$ & $\begin{array}{l}\mathrm{C} / \mathrm{C} \\
50(0.75) \\
44(0.68)\end{array}$ & $\begin{array}{l}\mathrm{C} / \mathrm{T} \\
16(0.24) \\
19(0.29)\end{array}$ & $\begin{array}{l}\mathrm{T} / \mathrm{T} \\
1(0.01) \\
2(0.03)\end{array}$ & $0.94 / 0.62^{\mathrm{a}}$ & $\begin{array}{l}\mathrm{C} \\
116(0.87) \\
107(0.82)\end{array}$ & $\begin{array}{l}\mathrm{T} \\
18(0.13) \\
23(0.18)\end{array}$ & 0.40 \\
\hline SNP9 & $\begin{array}{l}\text { Type II diabetic } \\
\text { Control subjects }\end{array}$ & $\begin{array}{l}\mathrm{A} / \mathrm{A} \\
3(0.04) \\
2(0.03)\end{array}$ & $\begin{array}{l}\mathrm{A} / \mathrm{G} \\
20(0.30) \\
24(0.38)\end{array}$ & $\begin{array}{l}\mathrm{G} / \mathrm{G} \\
44(0.66) \\
38(0.59)\end{array}$ & $0.93 / 0.63^{a}$ & $\begin{array}{l}\mathrm{A} \\
26(0.19) \\
28(0.22)\end{array}$ & $\begin{array}{l}\mathrm{G} \\
108(0.81) \\
100(0.78)\end{array}$ & 0.65 \\
\hline SNP12 & $\begin{array}{l}\text { Type II diabetic } \\
\text { Control subjects }\end{array}$ & $\begin{array}{l}\mathrm{C} / \mathrm{C} \\
61(0.98) \\
63(0.97)\end{array}$ & $\begin{array}{l}\mathrm{C} / \mathrm{T} \\
1(0.02) \\
2(0.03)\end{array}$ & $\begin{array}{l}\mathrm{T} / \mathrm{T} \\
0(0.00) \\
0(0.00)\end{array}$ & $0.30 / 0.59^{b}$ & $\begin{array}{l}\mathrm{C} \\
123(0.99) \\
128(0.98)\end{array}$ & $\begin{array}{l}\mathrm{T} \\
1(0.01) \\
2(0.02)\end{array}$ & 1.00 \\
\hline
\end{tabular}

All SNP markers are in the Hardy-Weinberg equilibrium. ${ }^{\mathrm{a}} \mathrm{df}=2,{ }^{\mathrm{b}} \mathrm{df}=1$. SNP1: ${ }^{\mathrm{c}}$ In primary screening of 69 patients and 65 control subjects,

\section{Discussion}

Linkage disequilibrium (LD) and association studies. The allelic and the genotypic frequencies of the six SNPs were the same for patients with Type II diabetes and control subjects.

To obtain an idea of the physical distances over which LD could be expected to be found at the $A K T 1$ locus in the Ashkenazi Jewish population, the extent of LD between pairs of SNPs (SNP1, 4, 5 and 9) was determined. Statistically significant LD was observed in both groups for pairs of closely spaced SNPs $(<14 \mathrm{~kb})$. Of note, SNP1 in the 5'-end of the gene was randomly associated with other SNPs only slightly more than $17 \mathrm{~kb}$ away in the 3'-end (SNP1SNP5, SNP1-SNP9), reinforcing previous concern that genome scans with SNP associations could require markers spaced at less than $3 \mathrm{~kb}$ intervals [10].

In summary, we conclude that the $A K T 1$ gene probably does not contribute to susceptibility to Type II diabetes in the Ashkenazi Jewish population. A better understanding of the genomic structure and the detection of informative intragenic SNPs, could, however, throw light on any role this gene might have in the pathogenesis of diabetes in other racial groups or in other diseases.

Acknowledgements. The authors would like to thank G. Skolnick for his help in preparing the manuscript. This work was supported in part by NIH grants DK16746 (MAP) and DK49583 (MAP), and the Diabetes Research and Training Center at the Washington University School of Medicine. A. Matsubara was the recipient of a Mentor Based Fellowship Award from the American Diabetes Association. $p$-value for Genotype chi-square test was 0.13 . Increasing subjects number (274 vs 147) revealed no significant association between SNP1 and Type II diabetes mellitus

\section{References}

1. Datta SR, Brunet A, Greenberg ME (1999) Cellular survival: a play in three Akts. Genes Dev. 13: 2905-2927

2. VanHaesebroeck B, Alessi DR (2000) The PI3K-PDK1 connection: more than just a road to PKB. Biochem J 346: $561-576$

3. Withers DJ, Burks DJ, Towery HH, Altamuro SL, Flint CL, White MF (1999) Irs-2 coordinates Igf-1 receptor-mediated beta cell development and peripheral insulin signalling. Nat Genet 23: 32-40

4. Kulkarni RN, Winnay JN, Daniels M et al. (1999) Altered function of insulin receptor substrate-1-deficient mouse islets and cultured beta cell lines. J Clin Invest 104: R69-R75

5. Tuttle R (2000) Overexpression of Constitutively Active Akt1 in the Pancreatic Beta Cell Improves Glucose Tolerance. American Diabetes Association Conference, June 9-14, San Antonio, Texas, ADA.

6. Hansen L, Fjordvang H, Rasmussen SK et al. (1999) Mutational analysis of the coding regions of the genes encoding protein kinase B-alpha and -beta, phosphoinositide-dependent protein kinase-1, phosphatase targeting to glycogen, protein phosphatase inhibitor-1, and glycogenin: lessons from a search for genetic variability of the insulin-stimulated glycogen synthesis pathway of skeletal muscle in NIDDM patients. Diabetes 48: 403-407

7. Ausubel FM, Brent R, Kingston RE, Moore DD, Seidman JG, Smith JA, Struhl K (1989) Current Protocols in Molecular Biology. John Wiley and Sons, Inc., New York

8. Permutt MA, Wasson J, Suarez BK et al. (2001) A Genome Scan for Type 2 Diabetes Mellitus Susceptibility Loci in a Genetically Isolated Population. Diabetes (In press)

9. Inoue H, Riggs AC, Tanizawa Yet al. (1996) Isolation, characterization, and chromosomal mapping of the human insulin promoter factor 1 (IPF1) gene. Diabetes 45: 789-794

10. Kruglyak L (1999) Prospects for whole-genome linkage disequilibrium mapping of common disease genes. Nature Genet 22: 139-144 